\title{
MOCKINGBIRD AT ROSTHERN
}

VICTOR C. FRIESEN, P.O. Box 65, Rosthern, SK SOK 3R0

When in 1964 Brazier listed 48 Saskatchewan sightings of the Northern Mockingbird (Mimus polyglottos), mostly from the previous 10 years, it seemed that the mockingbird would become established in our province. ${ }^{1}$ This has not occurred, the bird remaining, according to Smith, a "rare summer resident or transient." 3 And almost all of the records till now are for the southern part of the province, with only one originating north of Rosthern.

Then 16 June 1997, I was awakened by an early morning telephone call from Jake and Mary Neudorf, who farm three miles NW of town. They had been trying to contact me for the past two days to report a mockingbird on their yard. (I had been away at our Nature Saskatchewan's Summer Meet meanwhile to scout for birds in the Cypress Hills.)

I spent two hours with the Neudorfs that same morning. The mockingbird, obviously a male, sang constantly-from the housetop, a leafy tree, the garage roof, the washline. The Neudorf yard has a variety of trees and hedges, attracting many birds, as do the feeders and birdhouses. Thus the recent arrival always seemed to have other birds about-a bluebird sharing the washline, a chickadee flitting by, or a swallow buzzing him. The mockingbird paid them no heed but kept on singing-and singing.

The bird stayed exactly one week, leaving 20 June, apparently unable to attract a mate.

Following the bird's departure, I checked an anthology of "ornithological prose" and found these apt comments on our visitor by pioneer birder Thomas Nuttall ${ }^{2}$. Writing in the nineteenth century, this friend of Audubon refers to the mockingbird's motions as "perpetually animated" as he "spreads and closes his light and fanning wings, expands his silvered tail." The bird has "an Orphean talent,: his notes "distinguised by the rapidity of their delivery." "Even the hours of night," Nuttall continues, "he oft employs in song, serenading the ..... silent cottager to repose."2 Mary Neudorf might have a quibble with this last statement. Our mockingbird's singing kept her awake one night till 4:30 am.

1. BRAZIER,F.H. 1964. Status of the mockingbird in the northern Great Plains. Blue Jay 22:63-75.

2. NUTTALL, Thomas. 1939. Mockingbird. In a gathering of birds (D.C, Peattie, ed.). Dodd, Mead and Company, New York.

3. Smith, A.R, 1996. Atlas of Saskatchewan birds. Spec. Pub. No. 22, Sask. Nat. Hist. Soc., Regina, SK. 